\title{
Microbial conversion of food wastes for biofertilizer production with thermophilic lipolytic microbes
}

\author{
Shu-Hsien Tsai ${ }^{a}$, Ching-Piao Liu ${ }^{c}$, Shang-Shyng Yang ${ }^{a, b, *}$ \\ ${ }^{a}$ Institute of Microbiology and Biochemistry, National Taiwan University, Taipei 10617, Taiwan, ROC \\ ${ }^{\mathrm{b}}$ Department of Biochemical Science and Technology, National Taiwan University, Taipei 10617, Taiwan, ROC \\ ${ }^{\mathrm{c}}$ Department of Biological Science and Technology, Meiho Institute of Technology, Pingtung 91201, Taiwan, ROC
}

Received 15 March 2006; accepted 20 April 2006

Available online 5 July 2006

\begin{abstract}
Food waste is approximately one quarter of the total garbage in Taiwan. To investigate the feasibility of microbial conversion of food waste to multiple functional biofertilizer, food waste was mixed with bulking materials, inoculated with thermophilic and lipolytic microbes and incubated at $50^{\circ} \mathrm{C}$ in a mechanical composter. Microbial inoculation enhanced the degradation of food wastes, increased the total nitrogen and the germination rate of alfalfa seed, shortened the maturity period and improved the quality of biofertilizer. In food waste inoculated with thermophilic and lipolytic Brevibacillus borstelensis SH168 for 28 days, total nitrogen increased from $2.01 \%$ to $2.10 \%$, ash increased from $24.94 \%$ to $29.21 \%$, crude fat decreased from $4.88 \%$ to $1.34 \%$ and the $\mathrm{C} / \mathrm{N}$ ratio decreased from 18.02 to 17.65 . Each gram of final product had a higher population of thermophilic microbes than mesophilic microbes. Microbial conversion of food waste to biofertilizer is a feasible and potential technology in the future to maintain the natural resources and to reduce the impact on environmental quality.
\end{abstract}

(C) 2006 Elsevier Ltd. All rights reserved.

Keywords: Biofertilizer; Food wastes; Maturity; Thermophilic and lipolytic microbes

\section{Introduction}

Food waste is approximately $17.94-27.76 \%$ of the total garbage in Taiwan [1-3]. It has a high moisture and organic matter content, which is easily decomposed by microbes.

\footnotetext{
${ }^{*}$ Corresponding author. Tel.: +886223621519 ; fax: +886223679827.

E-mail address: ssyang@ntu.edu.tw (S.-S. Yang).
} 
It produces odor detrimental to environmental quality. Direct landfill of food wastes has created various problems such as putrid smells and leachate polluting ground and surface waters, while incineration treatment has been restricted due to its low calorific value and the cost of fuel supplements for operation [3,4]. Recycling food wastes can benefit the environment by reducing the amount of garbage disposed, promoting the fertility of soil and improving the physical and chemical properties of soil [5]. Moreover, recycling of food wastes reduce the unpleasant odors of garbage, benefits the sanitation of the environment, and decreases garbage collection-related spending.

Food waste is less harmful to the environment than industrial waste. Thus, composting of food waste is attracting considerable attention because it would significantly reduce the amount of waste and the product can be used as compost or biofertilizer which can be handled, stored, transported and applied to the field without adversely affecting the environment [6]. Although various composters are currently commercially available or several types of in-vessel composting systems have been developed for installation in food service establishments to manage food waste as a recyclable resource, it is difficult to maintain steady degradation due to the instability of the microflora within the composter due to the raw material, $\mathrm{pH}$, temperature and other environmental conditions [7-12]. Combining, food waste collection with mechanical composting and inoculation of thermophilic microbes to accelerate the composting has been examined. Food wastes were mixed with sawdust or waste leaves as bulking material, thermophilic microbes were inoculated and biofertilizer was prepared using the mechanical composter. The physical, chemical and microbiological properties of the biofertilizer were analyzed during the incubation. The effects of inoculant and raw material on the quality of biofertilizer were also investigated.

\section{Materials and methods}

\subsection{Raw materials}

Food wastes were collected from a National Taiwan University (NTU) restaurant. Despite daily variation of the menu in the restaurant, the compositions of food wastes changed only slightly in different batches as shown in Table 1. Waste leaves were also collected from the NTU Campus, and chopped to about $1 \mathrm{~cm}$ pieces using the composter in order to enhance the composting. Sawdust was purchased from the local market. Raw materials of food wastes were mixed with sawdust or waste leaves to adjust the initial moisture content $60-65 \%$ and the $\mathrm{C} / \mathrm{N}$ ratio between 20 and 25 .

\subsection{Composter operation}

The DY-8075E mechanical composter (Biorich Technology Corporation, Taiwan), having capacity of approximately 2501 was used. It has stainless steel blades for intermittent rotary agitation to ensure uniformity of the contents, a heating unit for the inner temperature and a heat sensor for monitoring the inner temperature.

The experiments were run under three different control regimes and the conditions are shown in Table 2. The first batch was run using the method provided by the Biorich Technology Corporation without inoculation, the second and third batches each with two bioreactors, were operated with inoculation, one with the thermophilic microbial 
Table 1

The properties of raw materials for the preparation of biofertilizer

\begin{tabular}{|c|c|c|c|c|c|c|c|}
\hline Material & $\mathrm{pH}$ & $\begin{array}{l}\text { Moisture } \\
\text { content } \\
(\%)\end{array}$ & Ash $(\%)$ & $\begin{array}{l}\text { Total organic } \\
\text { carbon }(\%)\end{array}$ & $\begin{array}{l}\text { Total } \\
\text { nitrogen } \\
(\%)\end{array}$ & Crude fat $(\%)$ & $\begin{array}{l}\text { Germination } \\
\text { rate }(\%)\end{array}$ \\
\hline
\end{tabular}

(a) The first batch

\begin{tabular}{|c|c|c|c|c|c|c|c|c|}
\hline Food & 4.67 & 76.53 & 12.59 & 41.86 & 3.01 & 15.31 & 0 & 13.91 \\
\hline waste & \pm 0.64 & \pm 0.34 & \pm 0.89 & \pm 0.65 & \pm 0.08 & \pm 0.32 & & \pm 0.79 \\
\hline Sawdust & 7.11 & 61.15 & 33.45 & 29.79 & 0.33 & 0.46 & 80.0 & 92.81 \\
\hline & \pm 0.02 & \pm 0.07 & \pm 0.42 & \pm 0.33 & \pm 0.06 & \pm 0.08 & \pm 3.0 & \pm 0.53 \\
\hline
\end{tabular}

\begin{tabular}{|c|c|c|c|c|c|c|c|c|}
\hline Food & 4.08 & 73.55 & 11.66 & 43.58 & 3.93 & 17.08 & 0 & 12.01 \\
\hline waste & \pm 0.03 & \pm 0.26 & \pm 0.41 & \pm 0.77 & \pm 0.02 & \pm 1.07 & & \pm 0.34 \\
\hline Waste & 6.15 & 11.64 & 25.19 & 45.43 & 0.71 & 4.01 & 67.0 & 64.00 \\
\hline Leaves & \pm 0.01 & \pm 0.27 & \pm 1.55 & \pm 0.18 & \pm 0.02 & \pm 0.82 & \pm 1.0 & \pm 1.02 \\
\hline
\end{tabular}

(c) The third batch

\begin{tabular}{|c|c|c|c|c|c|c|c|c|}
\hline Food & 4.70 & 81.12 & 12.95 & 39.27 & 2.36 & 12.62 & 0 & 15.30 \\
\hline waste & \pm 1.65 & \pm 0.73 & \pm 0.25 & \pm 0.16 & \pm 0.13 & \pm 0.25 & & \pm 1.12 \\
\hline Waste & 6.13 & 5.78 & 22.78 & 46.22 & 0.92 & 4.26 & 80 & 50.23 \\
\hline Leaves & \pm 0.01 & \pm 0.07 & \pm 2.72 & \pm 1.64 & \pm 0.01 & \pm 0.20 & \pm 3 & \pm 2.83 \\
\hline
\end{tabular}

Mean $\pm \operatorname{SD}(n=3)$.

inoculation (isolate SC6 in batch 2, and isolate SH169 in batch 3) (bioreactor A) and the other without inoculation as the control (bioreactor B). Five liters of inocula of test microbes $\left(>10^{7} \mathrm{CFU} \mathrm{ml}^{-1}\right.$ ) were applied at the beginning. The detailed operation conditions are listed in Table 2.

\subsection{Culture media and conditions}

Bacteria were counted at 30 or $50{ }^{\circ} \mathrm{C}$ after 2 days incubation on nutrient agar containing $\left(\mathrm{gl}^{-1}\right)$ beef extract 3.0, peptone 5.0, and agar 15.0 at $\mathrm{pH} 6.8 \pm 0.1$. Cellulolytic microbes were plated at 30 or $50{ }^{\circ} \mathrm{C}$ after 5 days incubation on Mandels-Reese medium with carboxymethylcellulose (CMC, Sigma) as the sole carbon source and sprayed with Congo red to show clear zones around the colonies [13]. Lipolytic microbes were assayed at 30 or $50{ }^{\circ} \mathrm{C}$ after 3 days incubation on Tributyrin agar with tributyrin (Merck) as a reactant. Degradation of this compound gave rise to clear zones surrounding the lipolytic colonies in the otherwise turbid culture medium. All the experiments were carried out in triplicate.

\subsection{Growth rate and enzyme activity}

The thermotolerant Streptomyces thermonitrificans NTU-88, isolate CH18 and Brevibacillus borstelensis SH168 were isolated from vegetable and fruit waste compost, animal manure compost and food waste compost, respectively. The Bacillus stearothermophilus ATCC 10149 was the indicator strain. Growth rate and enzyme activity were 
Table 2

The operation conditions of each batch to prepare biofertilizer

\begin{tabular}{|c|c|c|c|}
\hline Item & The first batch & The second batch & The third batch \\
\hline Pre-treatment (days) & & 7 & 7 \\
\hline $\begin{array}{l}\text { The frequency of } \\
\text { agitation rotate }\end{array}$ & & $\begin{array}{l}\text { Continuous agitation } \\
\text { (agitate } 10 \mathrm{~min} \text {, then stop } \\
\text { for } 20 \mathrm{~min} \text { ) }\end{array}$ & $\begin{array}{l}\text { Continuous agitation } \\
\text { (agitate } 10 \mathrm{~min} \text {, then stop } \\
\text { for } 20 \mathrm{~min} \text { ) }\end{array}$ \\
\hline Temperature $\left({ }^{\circ} \mathrm{C}\right)$ & & 50 & 50 \\
\hline \multirow{2}{*}{$\begin{array}{l}\text { Feeding day (Amount of } \\
\text { feeding in } \mathrm{kg} \text { ) }\end{array}$} & 35 & 21 & 4 \\
\hline & $\begin{array}{l}3(5) 6(10) 9(15) \\
12(25) 15(35) 18(50) \\
21(55) 24(55) 27(55) \\
30(55) 33(55)\end{array}$ & $7(40) 14(40) 21(50)$ & 1(70) 2(70) 3(70) 4(70) \\
\hline $\begin{array}{l}\text { The frequency of } \\
\text { agitation rotate }\end{array}$ & $\begin{array}{l}\text { Continuous agitation } \\
\text { (agitate } 10 \mathrm{~min} \text {, then stop } \\
\text { for } 20 \mathrm{~min} \text { ) }\end{array}$ & $\begin{array}{l}\text { Daily agitation once for } \\
10 \mathrm{~min}\end{array}$ & $\begin{array}{l}\text { Continuous agitation } \\
\text { (agitate } 10 \mathrm{~min} \text {, then stop } \\
\text { for } 20 \mathrm{~min} \text { ) }\end{array}$ \\
\hline Temperature $\left({ }^{\circ} \mathrm{C}\right)$ & 50 & 40 & 50 \\
\hline $\begin{array}{l}\text { Composting periods } \\
\text { (days) }\end{array}$ & & 49 & 28 \\
\hline $\begin{array}{l}\text { The frequency of } \\
\text { agitation rotate }\end{array}$ & & Once daily for $10 \mathrm{~min}$ & $\begin{array}{l}\text { Once every } 2 \text { to } 3 \text { days for } \\
10 \mathrm{~min}\end{array}$ \\
\hline Temperature $\left({ }^{\circ} \mathrm{C}\right)$ & & 40 & 40 \\
\hline Bulking materials & Sawdust $25 \mathrm{~kg}$ & Waste leaves $15 \mathrm{~kg}$ & Waste leaves $35 \mathrm{~kg}$ \\
\hline Food wastes (kg) & 415 & 130 & 280 \\
\hline $\begin{array}{l}\text { Gross weight of raw } \\
\text { materials }(\mathrm{kg})\end{array}$ & 440 & 145 & 315 \\
\hline $\begin{array}{l}\text { Gross time of experiment } \\
\text { (days) }\end{array}$ & 35 & 77 & 39 \\
\hline
\end{tabular}

measured as follows: nutrient agar for growth, Mandels-Reese medium for cellulase, Tributyrin agar for lipase, soluble starch-yeast extract medium for amylase and skim milk agar for protease activity.

\subsection{Chemical analysis}

Moisture content was determined by drying the sample at $105^{\circ} \mathrm{C}$ overnight to a constant weight. $\mathrm{pH}$ was measured in five times volume of distilled water equilibrated with sample for $1 \mathrm{~h}$ with $\mathrm{pH}$ meter (Good digital $\mathrm{pH}$ meter model 2002, Taiwan). Temperatures were determined under $50 \mathrm{~cm}$ depth of compost with a thermometer. Ash content in the dried sample was measured at $550{ }^{\circ} \mathrm{C}$. Total nitrogen was determined with a modified Kjeldahl method [14]. Total organic carbon determination was followed by the Walkley-Black method [15]. Crude fat was determined by extracting an oven-dried sample with hexane using Soxhlet extraction for $8 \mathrm{~h} \mathrm{[16].} \mathrm{Germination} \mathrm{rate} \mathrm{of} \mathrm{alfalfa} \mathrm{seed} \mathrm{was} \mathrm{assayed} \mathrm{using}$ 1:10 (W/V) aqueous suspensions of sample [17]. Experiments were carried out to obtain three measurements and statistical analysis of the results was performed using analysis of variance and Duncan's multiple range tests $(p=0.05)$ with the help of the Statistical Analysis System as previously described [18]. 


\section{Results and discussion}

\subsection{Isolation of thermophilic microbes}

There were 228 thermophilic isolates that had been isolated from animal waste compost, vegetable and fruit waste compost and food waste compost. It included 100 bacterial isolates, 52 actinomycete isolates and 76 fungal isolates. After series testing for cellulolytic, lipolytic, proteolytic and amylolytic activities, Brevibacillus borstelensis SH168 isolated from food waste compost, Streptomyces thermonitrificans NTU-88 and actinomycete isolate $\mathrm{CH} 18$ isolated from animal waste compost and Bacillus stearothermophilus ATCC 10149 purchased from Culture Collection and Research Center of Food Research and Development Institute, Hsin-Chu, Taiwan were used for biofertilizer preparation.

\subsection{Growth rate and enzyme activity of tested microbes}

The growth rates and enzymatic activities on the nutrient agar, Mendels-Reese medium, tributyrin agar, skim milk medium and soluble starch-yeast extract medium at $50{ }^{\circ} \mathrm{C}$ were measured for thermotolerant Bv. borstelensis SH168, B. stearothermophilus ATCC 10149, S. thermonitrificans NTU-88, and the actinomycete isolate $\mathrm{CH} 18$. Bv. borstelensis SH168 showed significantly high growth rates and enzyme activities on the nutrient agar, tributyrin agar, skim milk medium and soluble starch-yeast extract medium (Table 3). Therefore, Bv. borstelensis $\mathrm{SH} 168$ was used as inoculum to accelerate biofertilizer preparation of food wastes.

\subsection{Food waste biofertilizer prepared with eliminated type bioreactor}

Rapid and entire humification of a substrate essentially depends on its initial $\mathrm{C} / \mathrm{N}$ ratio which should be between 25 and 35 and a $\mathrm{pH}$ of 6.0-7.5 [19]. The food wastes used here had a $\mathrm{C} / \mathrm{N}$ ratio of $12.01-15.30$, while the $\mathrm{pH}$ values of the food wastes were between 4.08 and 4.70. Therefore, biofertilizer preparation with food wastes needs supplementation of bulk materials to adjust the initial $\mathrm{C} / \mathrm{N}$ ratio and the initial $\mathrm{pH}$. The food waste of university dormitory restaurant was mixed with sawdust and treated in the eliminated type bioreactor for 35 days using the method provided by Biorich Technology Corporation at $45-55^{\circ} \mathrm{C}$. It was found that the $\mathrm{pH}$ dropped from 7.11 to $4.90-5.00$, moisture content decreased from $61.15 \%$ to $4.79 \%$, ash decreased from $33.45 \%$ to $14.44 \%$ and then increased to $18.72 \%$, total organic carbon increased from $29.79 \%$ to $50.90 \%$, total nitrogen content increased from $0.33 \%$ to $2.23 \%$, the $\mathrm{C} / \mathrm{N}$ ratio decreased from 92.81 to 20.68-24.10, and the germination rate of alfalfa seed also dropped from $80 \%$ to $27 \%$ (Table 4). Microbial populations had a tendency to decrease suddenly from day 0 to day 7 due to the acidic environment, and then remain steady during the biofertilizer preparation. Total mesophilic microbes and mesophilic cellulolytic microbes decreased from $6.11 \times 10^{7}$ and $1.96 \times 10^{7} \mathrm{CFUg} \mathrm{g}^{-1}$ at day 0 , to $7.00 \times 10^{3}$ and $6.00 \times 10^{3} \mathrm{CFU} \mathrm{g}^{-1}$ at day 7 , respectively. Total thermophilic microbes and thermophilic cellulolytic microbes also decreased from $7.30 \times 10^{6}$ and $8.25 \times 10^{5} \mathrm{CFUg}^{-1}$ at day 0 , to $2.75 \times 10^{5}$ and $7.70 \times 10^{4} \mathrm{CFUg}^{-1}$ at day 7 , respectively. From the physical and chemical properties, food waste biofertilizer produced with the eliminated bioreactor was not a good quality product. 
Table 3

Colony size and clear zone of thermotolerant isolates on Mandels-Reese, tributyrin, skim milk and soluble starchyeast extract media at $50{ }^{\circ} \mathrm{C}$ for 4 days

\begin{tabular}{|c|c|c|c|}
\hline Test strain & Colony size $(\mathrm{mm})$ & Clear zone $(\mathrm{mm})$ & $\mathrm{CZ} / \mathrm{CS}$ \\
\hline \multicolumn{4}{|l|}{ (a) Mandels-Reese medium } \\
\hline Brevibacillus borstelensis SH168 & $10.0 \pm 1.0$ & $10.7 \pm 0.6$ & $1.08 \pm 0.16$ \\
\hline B. stearothermophilus ATCC 10149 & $5.7 \pm 0.6$ & $26.7 \pm 1.2$ & $4.73 \pm 0.44$ \\
\hline S. thermonitrificans NTU-88 & $21.3 \pm 0.6$ & $26.0 \pm 1.0$ & $1.22 \pm 0.06$ \\
\hline Isolate $\mathrm{CH} 18$ & $22.7 \pm 0.6$ & $34.7 \pm 1.2$ & $1.53 \pm 0.05$ \\
\hline \multicolumn{4}{|l|}{ (b) Tributyrin medium } \\
\hline Brevibacillus borstelensis SH168 & $38.7 \pm 0.6$ & $40.1 \pm 0.6$ & $1.04 \pm 0.06$ \\
\hline B. stearothermophilus ATCC 10149 & $6.0 \pm 0.6$ & $7.0 \pm 1.2$ & $1.17 \pm 0.14$ \\
\hline S. thermonitrificans NTU-88 & $8.7 \pm 0.6$ & $10.0 \pm 1.0$ & $1.15 \pm 0.06$ \\
\hline Isolate $\mathrm{CH} 18$ & $8.7 \pm 0.6$ & $11.0 \pm 1.2$ & $1.27 \pm 0.05$ \\
\hline \multicolumn{4}{|l|}{ (c) Skim milk medium } \\
\hline Brevibacillus borstelensis SH168 & $18.7 \pm 0.6$ & $31.3 \pm 0.6$ & $1.68 \pm 0.05$ \\
\hline B. stearothermophilus ATCC 10149 & $8.0 \pm 0.0$ & $16.7 \pm 0.6$ & $2.08 \pm 0.07$ \\
\hline S. thermonitrificans NTU-88 & $10.3 \pm 0.6$ & $20.0 \pm 1.0$ & $1.94 \pm 0.19$ \\
\hline Isolate $\mathrm{CH} 18$ & $17.3 \pm 0.6$ & $27.3 \pm 0.6$ & $1.58 \pm 0.07$ \\
\hline \multicolumn{4}{|l|}{ (d) Soluble starch-yeast extract medium } \\
\hline Brevibacillus borstelensis SH168 & $32.3 \pm 0.6$ & $33.7 \pm 0.6$ & $1.04 \pm 0.02$ \\
\hline B. stearothermophilus ATCC 10149 & $13.7 \pm 0.6$ & $21.3 \pm 0.6$ & $1.56 \pm 0.06$ \\
\hline S. thermonitrificans NTU-88 & $12.7 \pm 0.6$ & $21.0 \pm 1.0$ & $1.66 \pm 0.11$ \\
\hline Isolate $\mathrm{CH} 18$ & $14.3 \pm 0.6$ & $28.7 \pm 0.6$ & $2.00 \pm 0.12$ \\
\hline
\end{tabular}

Mean $\pm \operatorname{SD}(n=5)$.

Table 4

The properties of food waste biofertilizer in mechanical composter during the first batch preparation

\begin{tabular}{llrlllll}
\hline $\begin{array}{l}\text { Incubation } \\
\text { period (day) }\end{array}$ & $\mathrm{pH}$ & $\begin{array}{l}\text { Moisture } \\
\text { content }(\%)\end{array}$ & Ash (\%) & TOC (\%) & TN (\%) & $\begin{array}{l}\text { Germination } \\
\text { rate }(\%)\end{array}$ & C/N ratio \\
\hline 0 & $7.11 \pm 0.02$ & $61.15 \pm 0.07$ & $33.45 \pm 0.42$ & $29.79 \pm 0.33$ & $0.33 \pm 0.06$ & $80 \pm 3$ & $92.81 \pm 4.24$ \\
7 & $5.78 \pm 0.01$ & $13.63 \pm 0.18$ & $17.44 \pm 0.75$ & $49.53 \pm 0.39$ & $2.72 \pm 0.04$ & $77 \pm 1$ & $20.83 \pm 1.32$ \\
14 & $5.33 \pm 0.01$ & $6.41 \pm 0.58$ & $18.47 \pm 0.52$ & $54.92 \pm 0.59$ & $2.62 \pm 0.10$ & $76 \pm 3$ & $20.95 \pm 0.45$ \\
21 & $5.20 \pm 0.02$ & $4.55 \pm 0.59$ & $14.37 \pm 0.48$ & $53.58 \pm 0.76$ & $3.06 \pm 0.29$ & $55 \pm 4$ & $17.58 \pm 1.12$ \\
28 & $4.90 \pm 0.00$ & $9.98 \pm 0.00$ & $18.16 \pm 0.41$ & $50.57 \pm 1.10$ & $2.45 \pm 0.04$ & $45 \pm 4$ & $20.68 \pm 1.53$ \\
35 & $5.00 \pm 0.03$ & $4.79 \pm 0.06$ & $18.27 \pm 0.47$ & $50.90 \pm 0.16$ & $2.23 \pm 0.72$ & $27 \pm 4$ & $24.10 \pm 0.89$ \\
\hline
\end{tabular}

Mean $\pm \operatorname{SD}(n=3)$.

\subsection{Food waste biofertilizer prepared with the inoculation of thermophilic cellulolytic microbes}

The food waste of the university dormitory restaurant was mixed with waste leaves and treated with the composting bioreactors for 70 days, one was inoculated with thermophilic cellulolytic isolate SC6 (bioreactor A) and the other was without inoculation as the control (bioreactor B). Waste leaves $(15 \mathrm{~kg}$ ) were put in the bioreactor and blended for 5 days, then one of the bioreactors was inoculated with isolate SC $6\left(2.0 \times 10^{7} \mathrm{CFU} \mathrm{g}^{-1}\right)$. After 2 days, 
both of them were fed with food waste $6.2 \mathrm{~kg}$ daily for 21 days and then composted for another 49 days. It was found that the $\mathrm{pH}$ dropped from $6.13-6.17$ to $4.00-4.06$, moisture content decreased from $67.08-71.46 \%$ to $18.41-25.15 \%$, ash content decreased from $32.02-36.25 \%$ to $16.78-18.49 \%$ and then increased to $21.39-21.95 \%$, total organic carbon increased from $41.45-44.70 \%$ to $51.09-55.42 \%$ and then decreased to $43.23-46.64 \%$, total nitrogen content increased from $0.80-0.97 \%$ to $3.34-3.66 \%$, crude fat content increased from $2.79-4.51 \%$ to $23.65-24.62 \%$, the $\mathrm{C} / \mathrm{N}$ ratio decreased from $46.22-52.13$ to 12.76-12.94, and the germination rate of alfalfa seed dropped from $85-91 \%$ to $0 \%$ after day 14. Products from both bioreactors had similar physical and chemical properties except total organic carbon (Table 5). Total organic carbon of bioreactor A with the inoculation of thermophilic cellulolytic microbes decreased more rapidly than that of bioreactor B without inoculation due to the degradation of organic matter by the inoculated microbes. The germination rate of alfalfa seed decreased to $0 \%$ after day 14 due to the low $\mathrm{pH}$ value of the biofertilizer $(\mathrm{pH} 3.85-4.20)$ and the high crude fat content (16.49-17.38\%). The same phenomenon was also reported by Aoshima et al. [8]. The $\mathrm{pH}$ drop-off at the early stage of composting was associated with the degradation of organic matter and the formation of acidic metabolites. Low $\mathrm{pH}$ value inhibited severely the microbial and plant growth [20]. Beck-Friis et al. [9] indicated that short chain fatty acids, particularly lactic acid, were found at the beginning stage of composting.

Microbial populations had a tendency to decrease suddenly from day 0 to day 7 in the food waste mechanical composters during the second batch biofertilizer preparation. Total mesophilic microbes, mesophilic cellulolytic microbes and mesophilic lipolytic microbes decreased from 8.34-9.04 $\times 10^{8}, 5.67-7.02 \times 10^{8}$ and $4.12-5.97 \times 10^{8} \mathrm{CFU} \mathrm{g}^{-1}$ at day $0 ; 1.95-2.71 \times 10^{8}, 8.90 \times 10^{7}-2.02 \times 10^{8}$ and $1.89-2.27 \times 10^{8} \mathrm{CFU} \mathrm{g}^{-1}$ at day 21 , to $6.00 \times 10^{6}-1.10 \times 10^{7}, 1.00 \times 10^{4}-5.00 \times 10^{5}$ and $5.00-7.0010^{6} \mathrm{CFU} \mathrm{g}^{-1}$ at day 56 , respectively. While total thermophilic microbes, thermophilic cellulolytic microbes and thermophilic lipolytic microbes decreased from $7.97-8.99 \times 10^{8}, 7.26-8.37 \times 10^{8}$ and $1.94-4.19 \times 10^{8} \mathrm{CFU} \mathrm{g}^{-1}$ at day $0,3.33-4.46 \times 10^{8}, 1.49-1.75 \times 10^{8}$ and $9.40 \times 10^{7}-2.34 \times$ $10^{8} \mathrm{CFU} \mathrm{g}^{-1}$ at day 21 , to $4.30-6.80 \times 10^{7}, 2.00-4.00 \times 10^{5}$ and $1.10-4.30 \times 10^{7} \mathrm{CFU} \mathrm{g}^{-1}$ at day 56, respectively. From the physical and chemical properties, food waste biofertilizer preparation with the inoculation of thermophilic cellulolytic microbes in high fat content raw material did not yield a good quality product.

\subsection{Food waste biofertilizer prepared with the inoculation of thermophilic lipolytic microbes}

To investigate the production of biofertilizer with food waste containing high crude fat raw material, food waste of the university dormitory restaurant was treated with the composting bioreactors for 28 days, one was inoculated with thermophilic lipolytic $B v$. borstelensis SH 168 (bioreactor A) and the other was without inoculation as the control (bioreactor B). Waste leaves $(35 \mathrm{~kg}$ ) were put in the bioreactor and blended for 5 days, then one of the bioreactors was inoculated with $B v$. borstelensis $\mathrm{SH} 168\left(2.0 \times 10^{7} \mathrm{CFU} \mathrm{g}^{-1}\right)$. After 2 days, both of them were fed with food waste $70 \mathrm{~kg}$ daily for 4 days and then composted for another 28 days. The biofertilizer temperature in bioreactor A increased from 43 to $70{ }^{\circ} \mathrm{C}$ at day 3 due to the heavy growth of thermophilic lipolytic microbes, and then decreased gradually to $52^{\circ} \mathrm{C}$ at day 28 because of the maturity of biofertilizer; while it was $56^{\circ} \mathrm{C}$ at day 3 in bioreactor $\mathrm{B}$ and $45^{\circ} \mathrm{C}$ at day 28 . Temperature has been widely 
Table 5

The properties of the food waste biofertilizer in mechanical composter during the second batch preparation

\begin{tabular}{|c|c|c|c|c|c|c|c|c|c|}
\hline $\begin{array}{l}\text { Incubation } \\
\text { period (day) }\end{array}$ & $\begin{array}{l}\text { Temp. } \\
\left({ }^{\circ} \mathrm{C}\right)\end{array}$ & $\mathrm{pH}$ & $\begin{array}{l}\text { Moisture } \\
\text { content }(\%)\end{array}$ & Ash $(\%)$ & $\begin{array}{l}\text { TOC } \\
(\%)\end{array}$ & $\begin{array}{l}\mathrm{TN} \\
(\%)\end{array}$ & $\begin{array}{l}\text { Crude } \\
\text { fat }(\%)\end{array}$ & $\begin{array}{l}\text { Germination } \\
\text { rate }(\%)\end{array}$ & $\begin{array}{l}\mathrm{C} / \mathrm{N} \\
\text { ratio }\end{array}$ \\
\hline \multicolumn{10}{|c|}{ (a) Bioreactor $A$ with inoculation } \\
\hline \multirow[t]{2}{*}{0} & 42 & 6.13 & 7.96 & 26.39 & 39.39 & 0.85 & 3.53 & 85 & 46.85 \\
\hline & \pm 1 & \pm 0.07 & \pm 0.72 & \pm 2.54 & \pm 4.93 & \pm 0.01 & \pm 0.27 & \pm 0 & \pm 3.83 \\
\hline \multirow[t]{2}{*}{2} & 43 & 5.80 & 71.46 & 32.02 & 41.45 & 0.80 & 4.51 & 88 & 52.13 \\
\hline & \pm 2 & \pm 0.16 & \pm 0.30 & \pm 2.56 & \pm 3.03 & \pm 0.02 & \pm 0.19 & \pm 2 & \pm 2.59 \\
\hline \multirow[t]{2}{*}{7} & 48 & 5.22 & 72.83 & 18.80 & 46.01 & 2.17 & 9.85 & 91 & 21.18 \\
\hline & \pm 1 & \pm 0.04 & \pm 2.40 & \pm 2.16 & \pm 3.35 & \pm 0.05 & \pm 0.67 & \pm 1 & \pm 1.24 \\
\hline \multirow[t]{2}{*}{14} & 46 & 3.85 & 67.38 & 16.82 & 53.04 & 2.78 & 17.38 & 0 & 19.10 \\
\hline & \pm 2 & \pm 0.00 & \pm 1.04 & \pm 1.36 & \pm 4.36 & \pm 0.00 & \pm 0.12 & & \pm 1.42 \\
\hline \multirow[t]{2}{*}{21} & 48 & 3.91 & 66.94 & 16.78 & 48.18 & 2.54 & 19.36 & 0 & 18.94 \\
\hline & \pm 2 & \pm 0.11 & \pm 0.40 & \pm 0.82 & \pm 2.01 & \pm 0.01 & \pm 0.18 & & \pm 1.35 \\
\hline \multirow[t]{2}{*}{28} & 49 & 3.89 & 61.75 & 17.45 & 45.79 & 2.89 & 21.02 & 0 & 15.86 \\
\hline & \pm 2 & \pm 0.24 & \pm 0.29 & \pm 0.74 & \pm 2.05 & \pm 0.08 & \pm 0.21 & & \pm 1.62 \\
\hline \multirow[t]{2}{*}{35} & 51 & 3.98 & 57.21 & 17.85 & 51.09 & 3.37 & 19.35 & 0 & 15.17 \\
\hline & \pm 3 & \pm 0.12 & \pm 1.07 & \pm 0.91 & \pm 0.19 & \pm 0.16 & \pm 0.16 & & \pm 0.84 \\
\hline \multirow[t]{2}{*}{42} & 52 & 3.96 & 47.24 & 17.93 & 51.04 & 3.17 & 20.32 & 0 & 16.12 \\
\hline & \pm 2 & \pm 0.21 & \pm 1.80 & \pm 0.67 & \pm 0.83 & \pm 0.16 & \pm 0.19 & & \pm 0.56 \\
\hline \multirow[t]{2}{*}{49} & 56 & 3.96 & 38.28 & 18.63 & 50.02 & 3.38 & 20.55 & 0 & 14.78 \\
\hline & \pm 2 & \pm 0.11 & \pm 0.45 & \pm 0.41 & \pm 3.72 & \pm 0.15 & \pm 0.30 & & \pm 0.23 \\
\hline \multirow[t]{2}{*}{56} & 48 & 4.05 & 25.97 & 19.65 & 49.41 & 3.25 & 23.83 & 0 & 15.22 \\
\hline & \pm 1 & \pm 0.14 & \pm 0.04 & \pm 0.54 & \pm 0.36 & \pm 0.01 & \pm 0.38 & & \pm 0.28 \\
\hline \multirow[t]{2}{*}{63} & 43 & 3.90 & 26.61 & 21.26 & 42.71 & 3.23 & 22.19 & 0 & 13.23 \\
\hline & \pm 1 & \pm 0.11 & \pm 0.74 & \pm 0.86 & \pm 0.64 & \pm 0.04 & \pm 0.30 & & \pm 0.22 \\
\hline \multirow[t]{2}{*}{70} & 41 & 4.00 & 18.41 & 21.39 & 43.23 & 3.34 & 23.65 & 0 & 12.94 \\
\hline & \pm 2 & \pm 0.14 & \pm 1.04 & \pm 0.92 & \pm 0.79 & \pm 0.17 & \pm 0.47 & & \pm 0.75 \\
\hline
\end{tabular}

\section{(b) Bioreactor B without inoculation}

\begin{tabular}{|c|c|c|c|c|c|c|c|c|c|}
\hline \multirow[t]{2}{*}{0} & 44 & 6.17 & 8.73 & 30.36 & 42.27 & 0.92 & 3.68 & 89 & 46.16 \\
\hline & \pm 3 & \pm 0.23 & \pm 0.34 & \pm 1.80 & \pm 3.20 & \pm 0.08 & \pm 0.06 & \pm 2 & \pm 2.13 \\
\hline \multirow[t]{2}{*}{2} & 45 & 5.68 & 67.08 & 36.25 & 44.70 & 0.97 & 2.79 & 88 & 46.22 \\
\hline & \pm 3 & \pm 0.15 & \pm 1.64 & \pm 3.63 & \pm 0.48 & \pm 0.50 & \pm 0.23 & \pm 7 & \pm 2.42 \\
\hline \multirow[t]{2}{*}{7} & 48 & 5.34 & 63.81 & 21.92 & 42.86 & 2.31 & 9.12 & 91 & 18.57 \\
\hline & \pm 3 & \pm 0.10 & \pm 0.10 & \pm 1.81 & \pm 0.94 & \pm 0.02 & \pm 0.32 & \pm 1 & \pm 0.48 \\
\hline \multirow[t]{2}{*}{14} & 50 & 4.20 & 61.73 & 17.63 & 52.81 & 3.00 & 16.49 & 0 & 17.59 \\
\hline & \pm 3 & \pm 0.04 & \pm 0.15 & \pm 0.44 & \pm 4.12 & \pm 0.08 & \pm 0.18 & & \pm 0.84 \\
\hline \multirow[t]{2}{*}{21} & 51 & 3.79 & 61.08 & 18.49 & 47.42 & 2.91 & 22.80 & 0 & 16.33 \\
\hline & \pm 2 & \pm 0.04 & \pm 1.71 & \pm 0.69 & \pm 1.40 & \pm 0.13 & \pm 0.02 & & \pm 0.23 \\
\hline \multirow[t]{2}{*}{28} & 48 & 3.94 & 46.09 & 19.13 & 45.58 & 2.96 & 22.32 & 0 & 15.42 \\
\hline & \pm 2 & \pm 0.06 & \pm 3.21 & \pm 0.46 & \pm 2.42 & \pm 0.03 & \pm 0.29 & & \pm 0.37 \\
\hline \multirow[t]{2}{*}{35} & 49 & 3.98 & 33.84 & 19.48 & 55.42 & 3.74 & 22.56 & 0 & 14.83 \\
\hline & \pm 2 & \pm 0.10 & \pm 1.78 & \pm 0.42 & \pm 0.48 & \pm 0.03 & \pm 0.31 & & \pm 0.65 \\
\hline \multirow[t]{2}{*}{42} & 46 & 4.01 & 24.40 & 19.75 & 50.55 & 3.55 & 25.50 & 0 & 14.25 \\
\hline & \pm 2 & \pm 0.13 & \pm 0.29 & \pm 0.66 & \pm 1.90 & \pm 0.15 & \pm 0.53 & & \pm 0.73 \\
\hline \multirow[t]{2}{*}{49} & 44 & 4.02 & 23.27 & 19.83 & 48.10 & 3.59 & 24.49 & 0 & 13.44 \\
\hline & \pm 2 & \pm 0.11 & \pm 1.72 & \pm 1.21 & \pm 3.24 & \pm 0.16 & \pm 0.54 & & \pm 0.48 \\
\hline \multirow[t]{2}{*}{56} & 43 & 4.13 & 16.02 & 21.63 & 46.42 & 3.47 & 26.29 & 0 & 13.36 \\
\hline & \pm 1 & \pm 0.12 & \pm 0.23 & \pm 1.38 & \pm 0.70 & \pm 0.03 & \pm 0.37 & & \pm 0.21 \\
\hline \multirow[t]{2}{*}{63} & 42 & 4.03 & 27.94 & 22.97 & 37.26 & 3.67 & 24.84 & 0 & 10.15 \\
\hline & \pm 1 & \pm 0.08 & \pm 0.21 & \pm 1.20 & \pm 0.25 & \pm 0.01 & \pm 0.70 & & \pm 0.18 \\
\hline \multirow[t]{2}{*}{70} & 42 & 4.06 & 25.15 & 21.95 & 46.64 & 3.66 & 24.62 & 0 & 12.76 \\
\hline & \pm 1 & \pm 0.09 & \pm 0.49 & \pm 1.45 & \pm 1.01 & \pm 0.59 & \pm 1.02 & & \pm 0.11 \\
\hline
\end{tabular}

Mean $\pm \operatorname{SD}(n=3)$. 
recognized as one of the most important parameters in the composting processes. The temperature patterns have been reported to correlate with the microbial activities [21,22].

Initial moisture content was $64.81 \%$ in bioreactor $A$, this increased slightly to $67.72 \%$ due to metabolic water formation by the tested microbes [23-25] and then decreased gradually to $41.96 \%$ due to vaporization during preparation, while the initial moisture content was $65.23 \%$ in bioreactor $\mathrm{B}$, and then increased slightly during the incubation for the low temperature and vaporization. The $\mathrm{pH}$ decreased slightly due to the production of acidic metabolites, and then increased to 6.83-6.98 because of the assimilation of these acidic compounds. The $\mathrm{pH}$ changes were closely related to the decomposition of the food wastes [4]. The $\mathrm{pH}$ increased with degradation of soluble carbon began. Similar results were also found in animal waste compost and vegetable waste compost [26-28].

Ash content increased from $17.29-18.39 \%$ to $24.94-29.21 \%$, total organic carbon decreased slightly from $38.39-42.25 \%$ to $36.21-37.09 \%$, total nitrogen content increased from $1.40-1.59 \%$ to $2.01-2.10 \%$, crude fat content decreased from $7.99-8.02 \%$ to 1.34 $4.88 \%$, the $\mathrm{C} / \mathrm{N}$ ratio decreased from $26.55-27.51$ to $17.65-18.02$, and the germination rate of alfalfa seed increased from $10.50-34.00 \%$ to $97.50-98.00 \%$ (Table 6). Organic carbon decomposed to gaseous inorganic carbon which represented complete degradation [4]. The crude fat content decreased $83.23 \%$ during the incubation in bioreactor A with the inoculation of thermophilic and lipolytic Bv. borstelensis $\mathrm{SH} 168$, while crude fat content

Table 6

The properties of the food waste biofertilizer in mechanical composter during the third batch preparation

\begin{tabular}{|c|c|c|c|c|c|c|c|c|c|}
\hline $\begin{array}{l}\text { Incubation } \\
\text { period (day) }\end{array}$ & $\begin{array}{l}\text { Temp. } \\
\left({ }^{\circ} \mathrm{C}\right)\end{array}$ & $\mathrm{pH}$ & $\begin{array}{l}\text { Moisture } \\
\text { content }(\%)\end{array}$ & Ash $(\%)$ & $\begin{array}{l}\text { TOC } \\
(\%)\end{array}$ & $\begin{array}{l}\mathrm{TN} \\
(\%)\end{array}$ & $\begin{array}{l}\text { Crude } \\
\text { fat }(\%)\end{array}$ & $\begin{array}{l}\text { Germination } \\
\text { rate }(\%)\end{array}$ & $\begin{array}{l}\mathrm{C} / \mathrm{N} \\
\text { ratio }\end{array}$ \\
\hline \multicolumn{10}{|c|}{ (a) Bioreactor $A$ with inoculation } \\
\hline \multirow[t]{2}{*}{0} & 43 & 4.55 & 64.81 & 17.29 & 42.25 & 1.59 & 7.99 & 0 & 26.55 \\
\hline & \pm 3 & \pm 0.01 & \pm 1.96 & \pm 0.29 & \pm 0.99 & \pm 0.03 & \pm 0.07 & & \pm 0.77 \\
\hline \multirow[t]{2}{*}{7} & 70 & 4.22 & 67.72 & 21.14 & 41.10 & 1.84 & 5.72 & 10.50 & 22.28 \\
\hline & \pm 5 & \pm 0.01 & \pm 0.23 & \pm 0.56 & \pm 2.86 & \pm 0.47 & \pm 0.17 & \pm 1.41 & \pm 1.25 \\
\hline \multirow[t]{2}{*}{14} & 61 & 4.21 & 65.53 & 23.22 & 40.63 & 1.97 & 5.56 & 48.00 & 20.63 \\
\hline & \pm 4 & \pm 0.06 & \pm 1.06 & \pm 0.16 & \pm 0.25 & \pm 0.02 & \pm 0.10 & \pm 2.83 & \pm 0.29 \\
\hline \multirow[t]{2}{*}{21} & 55 & 4.84 & 57.77 & 24.84 & 39.75 & 2.06 & 4.84 & 95.00 & 19.33 \\
\hline & \pm 3 & \pm 0.02 & \pm 0.86 & \pm 0.23 & \pm 0.75 & \pm 0.06 & \pm 0.21 & \pm 1.41 & \pm 0.83 \\
\hline \multirow[t]{2}{*}{28} & 52 & 6.83 & 41.96 & 29.21 & 37.09 & 2.10 & 1.34 & 97.50 & 17.65 \\
\hline & \pm 3 & \pm 0.06 & \pm 0.64 & \pm 0.89 & \pm 0.35 & \pm 0.08 & \pm 0.09 & \pm 0.71 & \pm 0.61 \\
\hline \multicolumn{10}{|c|}{ (b) Bioreactor B without inoculation } \\
\hline \multirow[t]{2}{*}{0} & 41 & 3.91 & 65.23 & 18.39 & 38.39 & 1.40 & 8.02 & 0 & 27.51 \\
\hline & \pm 3 & \pm 0.04 & \pm 1.74 & \pm 1.71 & \pm 1.11 & \pm 0.01 & \pm 0.13 & & \pm 1.02 \\
\hline \multirow[t]{2}{*}{7} & 56 & 3.99 & 67.49 & 21.90 & 37.39 & 1.74 & 6.61 & 0 & 21.55 \\
\hline & \pm 3 & \pm 0.01 & \pm 1.00 & \pm 1.09 & \pm 0.98 & \pm 0.08 & \pm 0.10 & & \pm 0.97 \\
\hline \multirow[t]{2}{*}{14} & 50 & 5.33 & 68.03 & 22.17 & 37.08 & 1.80 & 6.22 & 34.00 & 20.65 \\
\hline & \pm 3 & \pm 0.02 & \pm 0.86 & \pm 0.45 & \pm 0.31 & \pm 0.02 & \pm 0.09 & \pm 2.83 & \pm 0.53 \\
\hline \multirow[t]{2}{*}{21} & 47 & 6.23 & 69.01 & 24.96 & 36.39 & 1.92 & 5.35 & 87.00 & 18.95 \\
\hline & \pm 2 & \pm 0.11 & \pm 0.81 & \pm 1.71 & \pm 0.66 & \pm 0.03 & \pm 0.10 & \pm 1.41 & \pm 0.37 \\
\hline \multirow[t]{2}{*}{28} & 45 & 6.98 & 69.47 & 24.94 & 36.21 & 2.01 & 4.88 & 98.00 & 18.02 \\
\hline & \pm 2 & \pm 0.01 & \pm 0.35 & \pm 1.56 & \pm 0.22 & \pm 0.04 & \pm 0.06 & \pm 2.83 & \pm 0.21 \\
\hline
\end{tabular}

Mean $\pm \operatorname{SD}(n=3)$. 
decreased only $39.15 \%$ in bioreactor B without inoculation. In addition, inoculation of thermophilic and lipolytic Bv. borstelensis $\mathrm{SH} 168$ also reduced the organic acid concentration and stimulated the germination rate of alfalfa seed. Excess oil in the food waste had an inhibitory effect on the biodegradation and caused oil accumulation within the composter [9]. From these observations, the time course of degradation of food wastes could be deduced. Inoculation of fat tolerant and decomposing microbes, or adjusting the substrate $\mathrm{pH}$, may increase the decomposition rate of these fat-containing materials. The results of the composting experiments revealed that as compared to control, a significant reduction in percentages of crude fat, total organic carbon and the $\mathrm{C} / \mathrm{N}$ ratio took place. Therefore, inoculation of thermophilic and lipolytic microbes enhanced the organic matter degradation, decreased total carbon content and the $\mathrm{C} / \mathrm{N}$ ratio, increased ash, total nitrogen content and the germination rate. Inoculation of appropriate microbes to food waste could thus shorten the period for maturity and improve the quality of biofertilizer $[21,26,29,30]$. Nakasaki et al. [31,32] also reported that liming to control the $\mathrm{pH}$ or inoculation of Bacillus licheniformis clearly enhanced the carbon turnover by shortening the low $\mathrm{pH}$ phase when composting in a laboratory-scale composting reactor at $60^{\circ} \mathrm{C}$. Total organic carbon content of bioreactor $\mathrm{A}$ with the inoculation of thermophilic and lipolytic microbes decreased more rapidly than that of bioreactor B without inoculation due to the degradation of organic matter by the inoculated microbes. Proper composting effectively destroys pathogens and weed seeds through the metabolic heat generated by microorganisms during the process [21,33]. Such biofertilizers are not only suitable for use as a soil conditioner and fertilizer, but can also suppress soil-borne and foliar plant pathogens $[21,34,35]$.

Total mesophilic microbes, mesophilic cellulolytic microbes and mesophilic lipolytic microbes were $1.40 \times 10^{7}-7.05 \times 10^{8}, 7.00 \times 10^{6}-4.03 \times 10^{8}$ and $7.00 \times 10^{6}-6.13 \times 10^{8} \mathrm{CFU} \mathrm{g}^{-1}$ at day 0 ; and $1.90 \times 10^{7}-1.02 \times 10^{9}, 2.00 \times 10^{6}-1.20 \times 10^{7}$ and $2.00 \times 10^{6}-1.20 \times 10^{7} \mathrm{CFU} \mathrm{g}^{-1}$ at day 28 , respectively. While total thermophilic microbes, thermophilic cellulolytic microbes and thermophilic lipolytic microbes were $1.36-8.18 \times 10^{8}, 8.70 \times 10^{7}-4.54 \times 10^{8}$ and $5.10 \times 10^{7}$ $-4.18 \times 10^{8} \mathrm{CFU} \mathrm{g}^{-1}$ at day 0 , and $7.40 \times 10^{7}-1.90 \times 10^{9}, 4.00 \times 10^{6}-1.82 \times 10^{9}$ and $4.00 \times 10^{6}$ $-1.82 \times 10^{9} \mathrm{CFU} \mathrm{g}^{-1}$ at day 28 , respectively. The thermophilic microbe count was higher than that of the mesophilic microbes in bioreactor A due to the inoculation of the thermophilic lipolytic microbe Bv. borstelensis $\mathrm{SH} 168$. Low fat content product favored microbial and plant growth. From the physical and chemical properties, biofertilizer prepared with food waste using thermophilic lipolytic microbes is a feasibile and potential method for the future to maintain nature resources and to reduce the impact of waste on environmental quality.

\section{Acknowledgments}

The authors thank Professor C. M. Lai for his technical assistances, The Biorich Technology Corporation for offering the mechanical composter, and the National Science Council of the Republic of China (NSC 91-2317-B005-006) and the Bureau of Environmental Protection of Taipei City Government for financial support.

\section{References}

[1] Wu SH, Loisel P. The composting of table scraps and its applications in organic agriculture. In: Proceedings of the Alexander von Humboldt-Foundation-2001 Taipei Forum, Taipei, 2001. p. 9-26. 
[2] Tsai SH, Wei CB, Yang SS. Quality of food waste compost produced by local autonomy group in Taipei City. J Biomass Energy Soc China 2002;21:103-17.

[3] Yang SS, Tsai SH. Treatment and re-utilization of food wastes. Newslett Legist Yuan 2002;30(3):38-53.

[4] Yun YS, Park JI, Suh MS, Park JM. Treatment of food wastes using slurry-phase decomposition. Biores Technol 2000;73:21-7.

[5] Park JI, Yun YS, Park JM. Long-term operation of slurry bioreactor for decomposition of food wastes. Biores Technol 2002;84:101-4.

[6] Debosz K, Petersen SO, Kube LK, Ambus P. Evaluating effects of sewage sludge and household compost on soil physical, chemical and microbiological properties. Appl Soil Ecol 2002;19:237-48.

[7] Choi MH, Park YH. The influence of yeast on thermophilic composting of food waste. Lett Appl Microbiol 1998;26:175-8.

[8] Aoshima M, Pedro MS, Haruta S, Ding L, Fukada T, Kigawa A, et al. Analyses of microbial community within a composter operated using household garbage with special reference to the addition of soybean oil. J Biosci Bioeng 2001;91:456-61.

[9] Beck-Friis B, Smårs S, Jönsson H, Kirchmann H. Gaseous emissions of carbon dioxide, ammonia and nitrous oxide from organic household waste in a compost reactor under different temperature regimes. J Agric Eng Res 2001;78(4):423-30.

[10] Pedro MS, Haruta S, Hazaka M, Shimada R, Yoshida C, Hiura K, et al. Denaturing gradient gel electrophoresis analyses of microbial community from field-scale composter. J Biosci Bioeng 2001;91:159-65.

[11] Smårs S, Jönsson H, Beck-Friis B, Kirchmann H. An advanced experimental composting reactor for systematic simulation studies. J Agric Eng Res 2001;78(4):415-22.

[12] Barrington S, Choiniere D, Trigui M, Knight W. Compost convective airflow under passive aeration. Biores Technol 2003;86:259-66.

[13] Teather RM, Wood PJ. Use of Congo red-polysaccharide interactions in enumeration and characterization of cellulolytic bacteria from the bovine rumen. Appl Environ Microbiol 1982;37:777-80.

[14] Yang SS, Chang HL, Wei CB, Lin HC. Reduce waste production with modified Kjeldahl method for nitrogen measurement. J Biomass Energy Soc China 1991;10:147-55.

[15] Nelson DW, Sommers LE. Total carbon, organic carbon and organic matter. In: Page AL, editor. Methods of Soil Analysis, Part 2. Chemical and Microbiological Properties. second edition. Wisconsin: The American Society of Agronomy; 1982. p. 539-80.

[16] Hanahan DJ. Lipid chemistry. New York: John Wiley and Sons; 1960.

[17] Yang SS. Preparation and characterization of compost. J Biomass Energy Soc China 1997;16:47-62.

[18] SAS Institute. SAS/STAT user's guide, release 6.03. SAS Institute. Cary, NC, 2002.

[19] Golueke CG. Bacteriology of composting. Biocycle 1992:55-7.

[20] Smårs S, Gustafsson L, Beck-Friis B, Jönsson H. Improvement of the composting time for household waste during an initial low pH phase by mesophilic temperature control. Biores Technol 2002;84:237-41.

[21] Yang SS. Recent advance in composting. In: Huang SF, Pan SY, Kao CF, editors. Proceedings of the international seminar on issues in the management of agricultural resources. September 6-8, 2000. Food and Fertilizer Technology Center for the Asian and Pacific Region (FFTC). Taipei, Taiwan: National Taiwan University; 2000. p. 166-85.

[22] Tiquia SM, Tam NFY. Characterization and composting of poultry litter in forced-aeration piles. Process Biochem 2002;37:869-80.

[23] Yang SS. Protein enrichment of sweet potato residue with amylolytic yeasts by solid state fermentation. Biotech Bioeng 1988;32:886-90.

[24] Yang SS, Chiu WF. Protease production with sweet potato residue by solid state fermentation. Chin J Microbiol Immunol 1986;19:276-88.

[25] Yang SS, Yuan SS. Oxytetracycline production by Streptomyces rimosus in solid state fermentation of sweet potato residue. World J Microbiol Biotech 1990;6:236-44.

[26] Chen KS, Lin YS, Yang SS. Isolation and application of thermo-tolerant microbes in composting. J Agric Assoc China New Series 1998;183:97-112.

[27] Yang SS, Chang SC, Wei CB. Properties of livestock and poultry wastes during composting in farms. J Biomass Energy Soc China 2000;19:49-61.

[28] Pai CR, Wu CF, Sun RY, Wei CB, Yang SS. Composition analysis of livestock and poultry wastes during composting. J Biomass Energy Soc China 2003;22:57-71.

[29] Chin HS, Huang CC, Chen KS, Yang SS. Cellulase activity of thermophilic actinomycetes and their effect on the quality of rice straw compost. J Agric Assoc China, New Series 1999;185:58-71. 
[30] Yang SS, Chen KS. Application of thermophilic microbes for preparing biofertilizers. Plant Prot Bull Spec Publ New 2003;5:267-91.

[31] Nakasaki K, Yaguchi H, Sasaki Y, Kubota H. Effects of pH control on composting of garbage. Waste Manage Res 1993;11:117-25.

[32] Nakasaki K, Uehara N, Kataoka M, Kubota H. The use of Bacillus licheniformis HA1 to accelerate composting of organic waste. Comp Sci Utiliz 1996;4(4):47-51.

[33] Crawford JH. Composting of agricultural wastes: a review. Process Biochem 1983;2:14-8.

[34] Hadar Y, Mandelbaum R. Suppressive compost for biocontrol of soilborne plant pathogens. Phytoparasitica 1992;20:113-6.

[35] Zang W, Han DY, Dick WA, Davis KR, Hoitink HAJ. Compost and compost water extract-induced systemic acquired resistance in cucumber and Arabidopsis. Phytopathol 1998;88:450-5. 